\title{
ダム貯水池における湖上風の現地観測と その推定方法に関する研究
}

\author{
松永真弥 $1 \cdot$ 横山勝英 $2 \cdot$ 上田博茂 $3 \cdot$ 小泉 明 $4 \cdot$ 山崎公子 5 \\ ・兼安智也 6 -木村慎一 6 \\ 1 非会員 首都大学東京大学院 都市基盤環境学域（干192-0397 東京都八王子市南大沢 1-1） \\ E-mail: matsunaga-shinya@ed.tmu.ac.jp \\ 2 正会員 首都大学東京大学院准教授 都市基盤環境学域（干192-0397 東京都八王子市南大沢 1-1） \\ E-mail: k-yoko@tmu.ac.jp \\ 3 正会員 元・首都大学東京大学院 都市基盤環境学域（干192-0397 東京都八王子市南大沢 1-1） \\ 現・八千代エンジニアリング株式会社 九州支店河川・水工部（テ810-0062 福岡県福岡市中央区荒戸 2-1-5） \\ 4フェロー会員 首都大学東京大学院特任教授 都市基盤環境学域（一192-0397 東京都八王子市南大沢 1-1） \\ 5 正会員 首都大学東京大学院助教 都市基盤環境学域（†192-0397 東京都八王子市南大沢 1-1） \\ 6非会員 東京都水道局浄水部（干163-8001 東京都新宿区西新宿 2-8-1）
}

\begin{abstract}
小河内貯水池において湖上風の空間分布特性を把握するために，ハンディー風向風速計をブイシステム に取り付けて 8 地点に設置し, 夏季の連続観測を実施した. 地点ごとに風速の強さや風向は異なり, 谷筋 に沿った風が吹いていることが分かった。ダム管理所の敷地内にあるアメダスデータと比較したところ, 湖上の方が風速が大きかった。湖上観測点における卓越風向の風上距離を地図上で求め, 風速比（湖上／ アメダス）との関係を調べ，風上距離が長くなるほど風速比が大きくなることを示した．風向は昼・夜お よび晴・雨という条件によって場合分けできた。これらより, 湖上風の風速をアメダス風速と各地点の風 上距離から推定する式を提案した。提案式により実際の湖上風の時空間分布を概ね再現できた.
\end{abstract}

Key Words: wind distribution, meandering reservoir, AMeDAS, wind fetch, wind ratio

\section{1. はじめに}

湖沼や貯水池において，流動や鉛直混合を引き起こす 主要因の一つは風である. このため, 湖沼・貯水池の水 温成層の予測, 洪水時の濁水流動や富栄養化・貧酸素化 などの水質予測を適切に行うためには，湖上風に関する 正確な情報が必要である.

湖上の風速場は一様ではなく, 周辺地形の影響を受け ることが知られている. Endohら 1) 琵琶湖上におい て 3 隻の船を用いて風の観測を行い，各船は 6〜7 地点 において停泊し，5 分間の風向風速観測を実施した。 そ の結果，北西系の風は湖の北部で反時計回り，南部では 時計回りの渦度をもつことを示した. 鶴田・石川 2)は小 川原湖において湖上風の移動観測を行い，湖内の風の分 布特性は周辺地形の影響を強く受けていることを示して いる. 小林ら ${ }^{31}$ は小河内貯水池において同様の移動観測 を行い, 日中の風は谷筋に沿って吹くことや，蛇行部や 湖岸付近で風は弱くなり, 乱れる傾向を示した. さらに,
鶴田・石川 ${ }^{2)}$ は小川原湖を，小林ら ${ }^{4}$ は小河内貯水池を 対象として流動シミュレーションを行い，観測所一点の 風を全域一様に与えた場合と, 現地観測から推測された 風分布を与えた場合の比較を行った，その結果，流動の 再現性が異なり, 湖沼・貯水池では風の空間分布を与え ることが重要と指摘している.

しかし，実際には観測地点の場所や数は限られている. 霞ヶ浦や小川原湖には湖心観測所があるが，このような 例は少なく，また，大型貯水池であってもダム管理所に 観測所が設置されている程度である.

近年, 山岳地域における風力発電や送電線への荷重影 響を検討するため, 気象モデル WRF ${ }^{5} や \mathrm{LES}^{9}$ による山 岳地帯の風分布の推定と, 実測值との比較が行われてい る. これは主に山頂や尾根上に配置された構造物を対象 としており, 谷間にある貯水池では, 山を乗り越える風 の剥離の影響があるため, より予測は難しくなると考え られる．また，文献 5)ののような現場を対象とした検討 も行われていない. 
そこで本研究では，水面上で風向風速を計測できる 観測システムを考案し, 東京都奥多摩町の小河内貯水池 において湖上風の定点観測を複数地点でかつ長期間行っ た. そして得られたデータから，夏季の貯水池に吹く風 の分布特性を考察した. さらに，簡易的に風速場を知る ため, アメダス観測所のデータから任意の湖上地点にお ける風速を推定する手法について検討した.

\section{2. 研究方法}

\section{(1) 研究対象地の概要}

研究対象地は東京都奥多摩町に位置する小河内貯水池 である（図-1）。湛水面積は $4.25 \mathrm{~km}^{2}$ ，湛水延長は 13.87 $\mathrm{km}$, 最大湖幅は約 $750 \mathrm{~m}$, 最大水深は $142.5 \mathrm{~m}$ である. 周囲は標高約 $1500 \mathrm{~m}$ の山々が連なる山岳地帯であり, 湖水面との標高差は 500 1000 m に及ぶ. 貯水池は複雑 な形状を呈しており，全体として東西方向に伸びている. ダム堤体付近の東京都水道局水源管理事務所の敷地内 には，気象庁のアメダス観測所がある．観測項目は降水 量，気温，風向・風速，日照時間であり，敷地面から $10 \mathrm{~m}$ の高さに風車型風向風速計が取り付けられている. 下記に述べる観測期間の風速計の湖面からの高さは 17 〜23 m であった.

\section{(2) 観測システムの概要}

図-1 に示寸地点 $\mathrm{A} \sim \mathrm{H}$ の湖面上に，図-2 に示寸風向風 速計（NIELSEN KELLERMAN 社製，Kestrel 4500）を設置 した. この計器はレジャー向けのハンディ気象計（高さ $127 \mathrm{~mm}$ ，幅 $45 \mathrm{~mm}$ ，厚さ $28 \mathrm{~mm}$ ，重さ $102 \mathrm{~g}$ ) である. 風速の検定はメーカーにて行われているが，念のために 無風時に自動車で走行して, 確からしい值が表示されて いることを確認した.

コンパス内蔵型なので，固定式のように機器取り付け 時に方位を設定する必要は無いが，長期モニタリング用 の機器ではないため電池容量や防水性に課題がある.

リチウム電池を用いて 10 分間隔でデータを収集した ところ，実験室内では 1 ケ月可動したが，湖上では 10 〜14 日であった. 気象が時々刻々変化する環境下では 電力使用量が多くなると考えられた. また，日常防水で あることから，プラスチック製カバーを作成して本体を 覆うように装着し，防水加工を施した。

この風速計を湖上に長期間設置するため，ブイシステ ムを考案した（図-3）。強風や波浪が発生した際にも風 速計が垂直を保てるよう, 直径 $0.4 \mathrm{~m}$, 全長 $0.65 \mathrm{~m}$, 浮

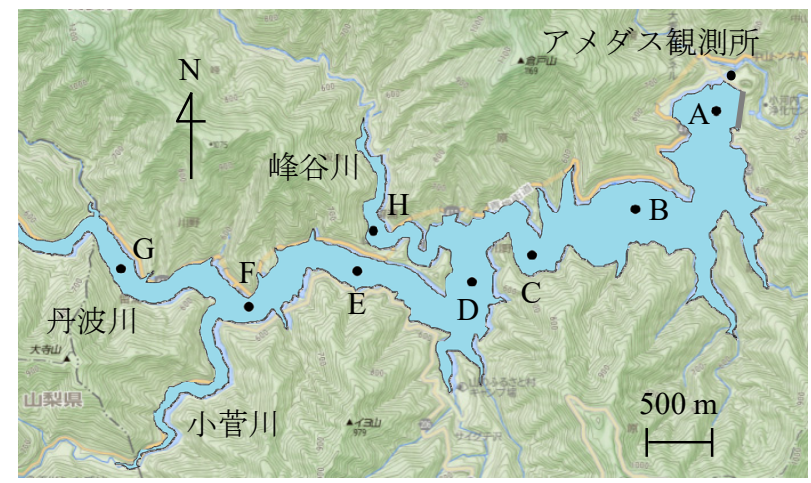

図-1 小河内貯水池と観測地点

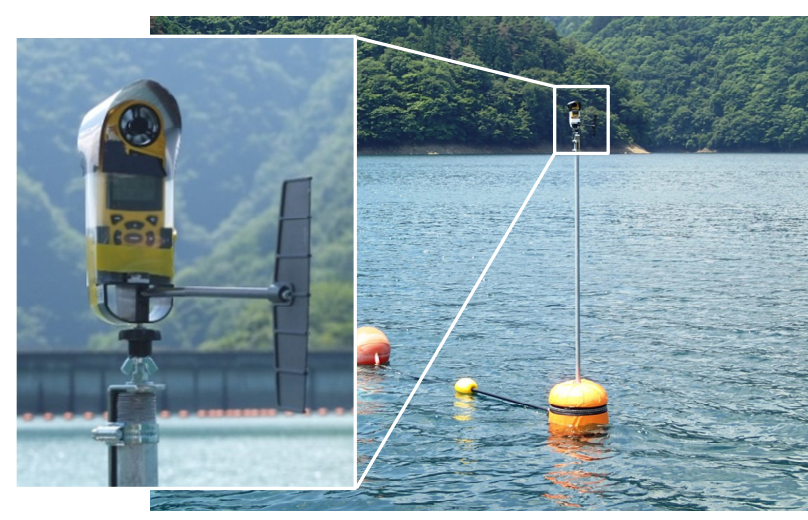

図-2 風向風速計と防水カバー

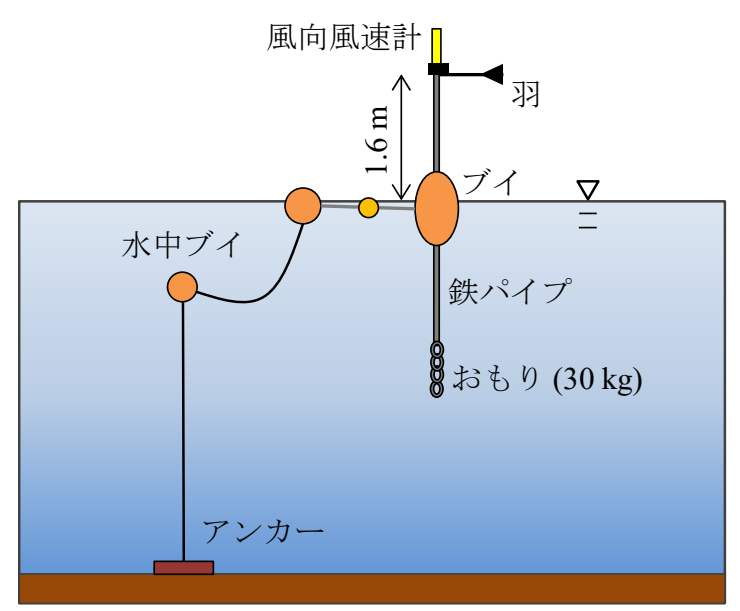

図-3 ブイシステムの概略図

力が $80 \mathrm{~kg}$ の俵型ブイに, 直径 $27.2 \mathrm{~mm}$, 全長 $4.0 \mathrm{~m}$ の鉄 パイプ (20 Aガス管) を通した. 下端に約 $30 \mathrm{~kg}$ のチェ ーンをおもりとしてつり下げ，上端には水面からの高さ が $1.6 \mathrm{~m}$ になるように風速計を取り付けた. 湖底には 20 $\mathrm{kg}$ のアンカーを沈め, 水中ブイを介して表層ブイに接 続した.

\section{(3) 現地観測}

湖上風の現地観測は，2015年 7 月 6 日から 10 月 9 日 までの約 3 ケ月間行い, 10 分間隔でデータを記録した. 


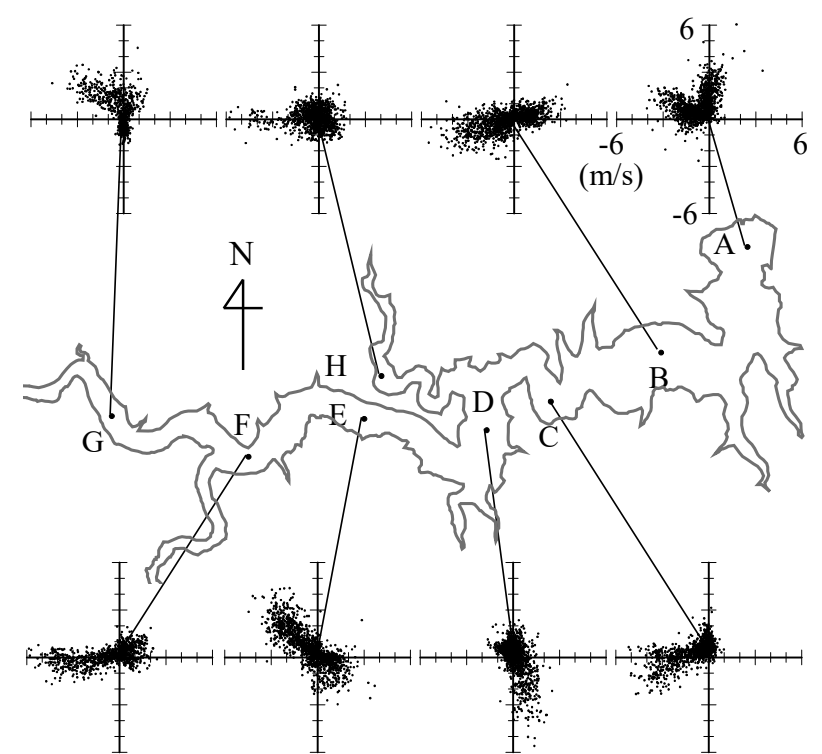

図-4 風向風速の散布図（8月 1 日～9月 30 日）

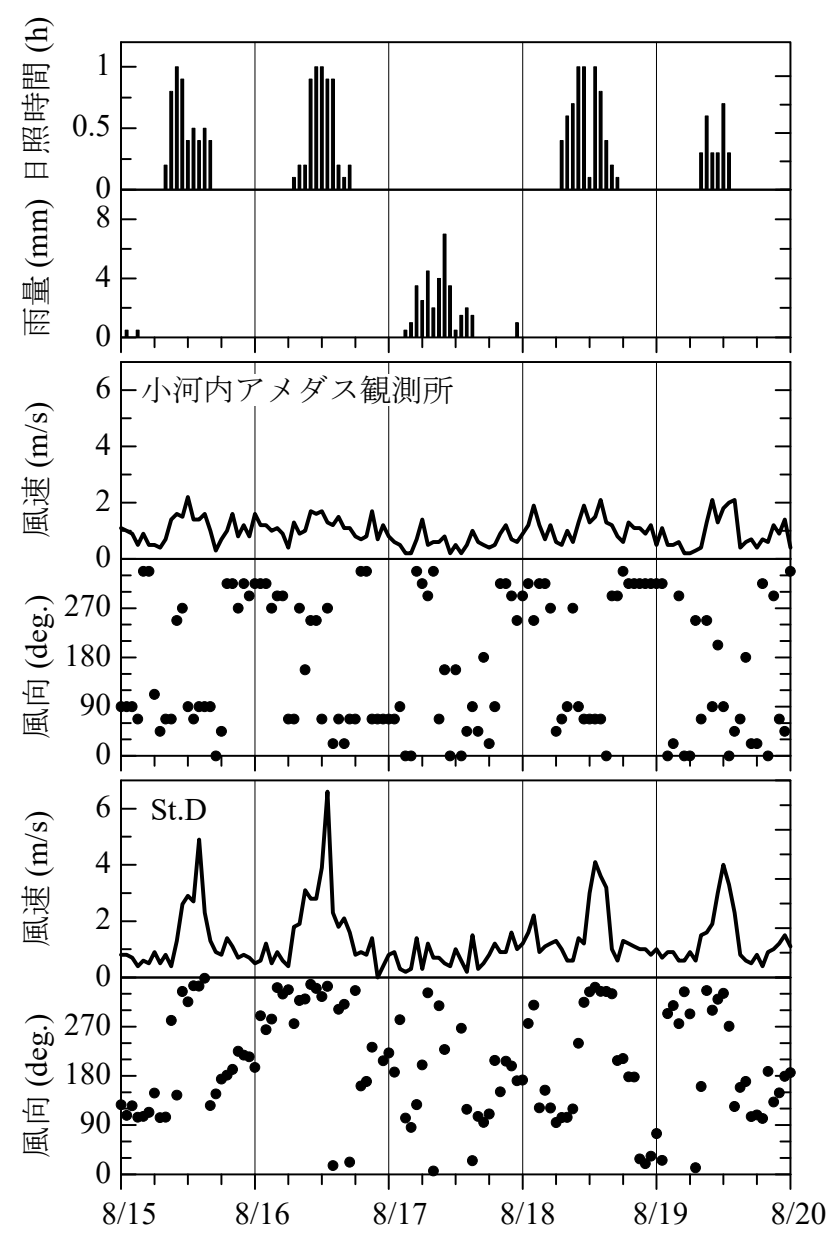

図-5 アメダスデータと湖上の風向・風速 $(\mathrm{StD})$

また，10 日おきに作業船で観測地点へ向かい，風向風 速計のメンテナンスとして，電池とカバーの交換，デー タ取り出し, デジタルコンパスの較正，窒素ガスの封入 を実施した。

風向は磁北基準で計測されるため, 偏角として 7.2 度 （西偏）を足すことで，真北基準の風向に補正した。

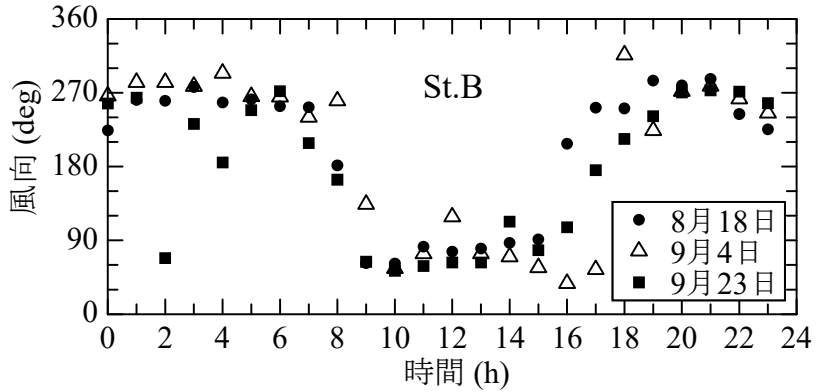

図-6 St.B の風向時系列（晴天）

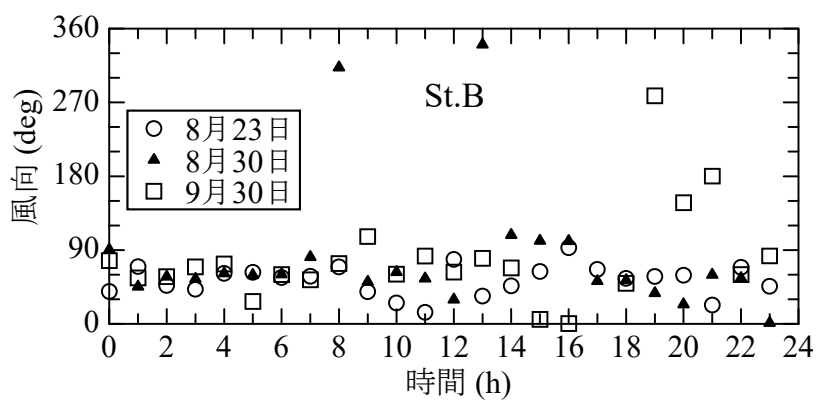

図-7 StB の風向時系列（量天・雨天）

\section{3. 観測結果}

\section{(1) アメダスデータと湖上風の時系列変化}

本システムによる湖上風のデータ取得率は，10日お きのメンテナンスにより全地点で 99 \%であった. また， 関東地方は 9 月 8 日に台風 18 号が通過したが，ブイシ ステムや風向風速計に目立ったトラブルは起きなかった。

図-4 に各地点における風ベクトルの終点をプロット した散布図を示す。地点ごとに卓越風向, 最大風速が異 なっており，1つの地点でも風向の特徵が見られる. 例 えば St. A では北に向かう風と西北西に向かう風が分布 している.これは，貯水池の谷地形が上流側は南に，下 流側は東南東に延びているためと考えられる. St. E では 西北西〜東南東に風が分布しており，貯水池の谷地形に 沿っている．また上流に向かう風の方が下流に向かう風 よりも強い傾向がある. St. H は明確な傾向は見られず 風も弱い. これは湖面幅が約 $150 \mathrm{~m}$ と狭く，90〜180 度 の蛇行が連続していることが原因と考えられる.

図-5に小河内アメダス観測所の日照時間・雨量，風 向風速と St. D における風向風速の時系列を示す. 風向 風速は 2 地点で大きく異なり，アメダス観測所では図示 した期間中の最大風速は約 $2.0 \mathrm{~m} / \mathrm{s}$ であるのに対し, St. D では $6.0 \mathrm{~m} / \mathrm{s}$ を超える時間帯も見られる. また, St. D で は晴天と雨天, 昼と夜の違いが明確である。これは他の 地点についても同様であり，アメダス観測所の風速值は 湖上風速よりも小さい傾向を示した.

次に, Sr. Bにおける風向を, 晴天時（図-6）と曇天・ 雨天時（図-7）に分けて示す。日照のある晴天日は（図 -6），午前 0 時から朝方にかけて 270 度を示し（上流か ら下流へに向かう風）, 午前 9 時頃に 90 度に変化する 
（下流から上流に向から風）。そして午後 4 時頃に再び 270 度に転向する. このように晴天日は，風向に周期性 があることが分かった，一方，日照がない日の風向の時 系列を見ると（図-7），一日を通して 0 90 度に分布し ており，下流から上流への風が卓越している.

小林ら ${ }^{3)}$ は，小河内貯水池において，晴天時の日中に は関東平野から奥多摩に吹き上がる風が生じ，夜間に関 東平野に吹き下りる風が吹くと考察している．晴天日に は日照と夜間冷却の影響で谷風・山風が発生し, 一方, 雨天日については一日の温度変化が少ないため, 風向の 変化が生じなかったと考えられる.

\section{4. アメダスデータを用いた湖上風速の推定}

後藤・柴木 》は，波浪及び高潮推算の外力となる海上 風に関して観測データをもとに解析し，内湾海上風は吹 送距離が長くなるとともに風速が増大寸ることを示した そこで，アメダス観測所の風向風速データを用いて，気 象条件と周辺地形から湖上風に変換することを試みる.

\section{（1）湖上風速の補正}

風速は地表に近いほど地表粗度の影響を受けて弱くな る. 水域の流動シミュレーションでは水面上 $10 \mathrm{~m}$ の高 さの風速 $u(10)$ が用いられることが多いので, 観測で得 られた水面上 $1.6 \mathrm{~m}$ の風速 $u(1.6) を u(10)$ に補正した.

風速の鈆直分布は対数則で表される.

$$
u(z)=\frac{u_{*}}{k} \ln \left(\frac{z}{z_{0}}\right)
$$

ここで, $u_{*}$ : 摩擦速度, $\kappa$ : カルマン定数, $z_{0}$ : 粗度高で ある. 粗度高 $\mathrm{z}_{0}$ は, 湖上では一般に $10^{-5} \sim 10^{-3}(\mathrm{~m})$ が用い られているので，ここでは $10^{4}(\mathrm{~m})$ とした. (1)式から(2) 式が求まる.

$$
u(10)=\frac{\ln (10)-\ln \left(z_{0}\right)}{\ln (1.6)-\ln \left(z_{0}\right)} u(1.6)
$$

これより, $u(1.6)$ から $u(10)$ への補正係数は 1.189 となった.

\section{(2) データの分類}

3 章で述べたように, 晴天・雨天と昼・夜で風の特徵 が異なることから，表-1 のようにデータを分類した. 午前 9 時から午後 4 時までを「昼間」，午後 5 時から午 前 8 時までを「夜間」とした。 また，日雨量が $1 \mathrm{~mm}$ 未 満で日照時間が 2 時間以上の日を「晴天」, 日雨量が 1 $\mathrm{mm}$ 以上で日照時間が 2 時間未満の日を「雨天」とした。 ただし，日照時間が 2 時間以上で，かつ日雨量が $1 \mathrm{~mm}$ 以上のときは，晴天とした.

\begin{tabular}{|c|c|c|c|c|}
\hline 分類 & 時間帯 & 雨量 & 日照 & 風向 \\
\hline 1（昼・晴） & \multirow{2}{*}{$\begin{array}{l}9: 00 \sim \\
16: 00\end{array}$} & $1.0 \mathrm{~mm}$ 未満 & $2 \mathrm{~h}$ 以上 & 下流 $\rightarrow$ 上流 \\
\hline 2 (昼•・雨) & & $1.0 \mathrm{~mm}$ 以上 & $2 \mathrm{~h}$ 末満 & 下流 $\rightarrow$ 上流 \\
\hline 3 (夜・晴) & \multirow{2}{*}{$\begin{array}{c}17: 00 \sim \\
8: 00\end{array}$} & $1.0 \mathrm{~mm}$ 末満 & $2 \mathrm{~h}$ 以上 & 上流 $\rightarrow$ 下流 \\
\hline 4 (夜• 雨) & & $1.0 \mathrm{~mm}$ 以上 & $2 \mathrm{~h}$ 未満 & 下流 $\rightarrow$ 上流 \\
\hline
\end{tabular}

表-1 データ分類の定義

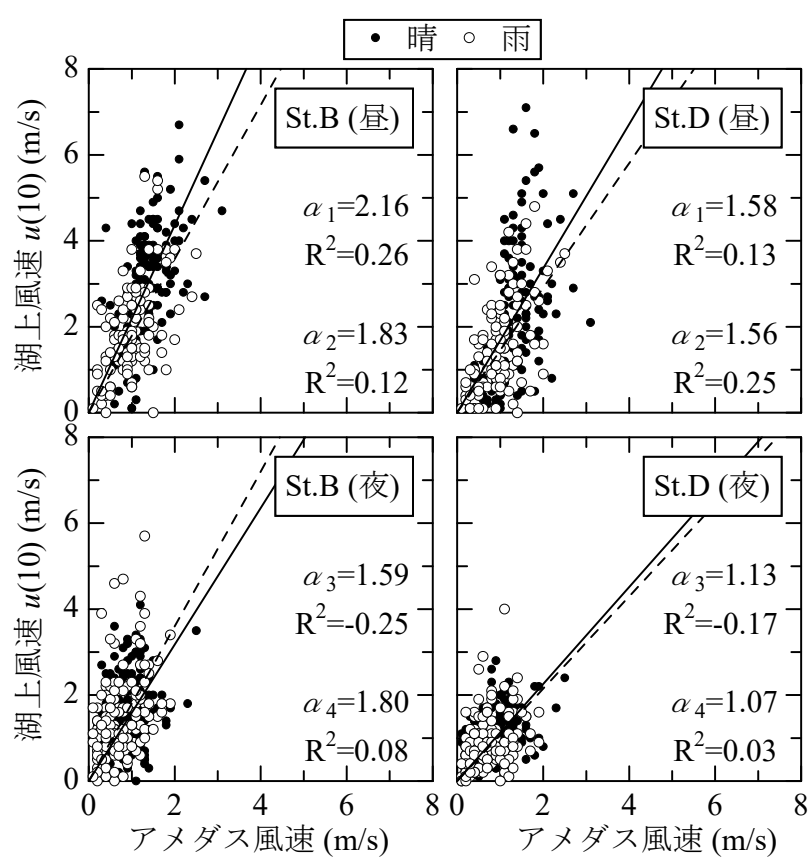

図-8 アメダス風速と湖上風速の比較

なお，表中の風向は，各分類の時間帯で卓越する風向 を示しており，分類の指標としては用いていない.

\section{（3）アメダス風速と湖上風速の相関}

図-8に，小河内アメダス観測所の風速と，St.Bおよび St. Dの $u(10) の$ 相関を分類別に示す. 図中の $\alpha$ は相関式の 傾きであり，アメダス風速に対する各地点風速の比を表 している. 図-5でも述べたように，晴天・雨天にかか わらず，小河内貯水池の湖上風速はアメダス風速よりも 高い值であることが明確になった，そのため，小河内貯 水池で流動シミュレーションを実施する際に, 代表風速 としてアメダス風速を用いると吹送流や鉛直混合を過小 評価すると予想される.

また，地形が東西に長い地点（St. B) で比の值が大き く, 周辺が蛇行している地点（St. D）で比が小さい傾向 が見られた。

\section{（4）アメダス風速による湖上風の推定}

アメダス風速から湖上風速を推定する方法を検討する. 各地点について風上距離 $L$ と風速比 $\alpha$ との関係を調べた. 


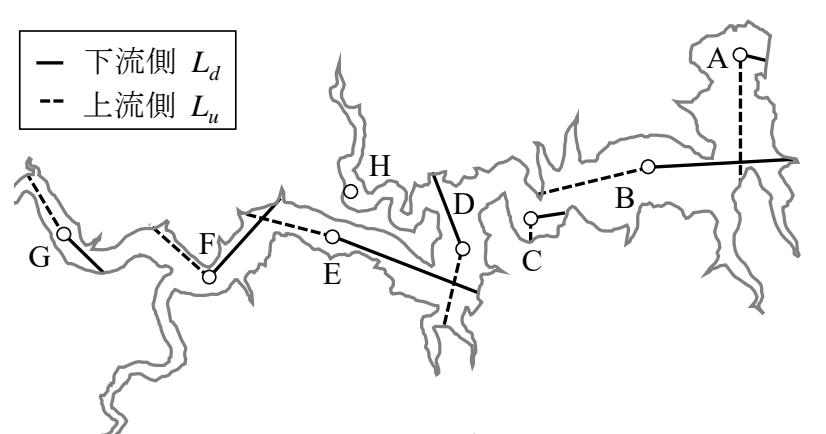

図-9 風上距離 $L$

$L$ は図-4 の卓越風向を参考にして，観測地点から風上側 の谷筋と概衩平行になるように，かつ風上側の湖岸への 見通しが最も長くなる距離とした．湖岸ではなく山腹斜 面までの距離とすることも考えられるが，小河内貯水池 は水面からの比高が $500 \mathrm{~m}$ 程度の急斜面に囲まれている ことから, 今回は簡単のために湖岸までの距離とした.

風向は分類によって変化し（表-1）, 分類 3（夜間・ 晴天）は上流加下流に向から風，分類 $1 ， 2 ， 4$ は下流 から上流に向かう風である. そこで，図-9 のように各 地点から下流側と上流側の距離を計測し, 下流側の風上

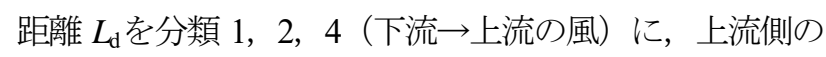

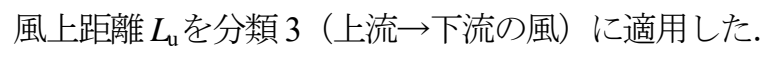

風上距離 $L_{\mathrm{d}} \cdot L_{\mathrm{u}}$ と風速比 $\alpha$ との関係は（図-10）, 昼と 夜で明確に分かれた．昼間は風速比 $a$ が 1.4〜2.3，夜は $\alpha$ が $0.9 \sim 1.8$ であり, 昼の方がアメダス風速に対する湖上 風の増幅率が大きい. 図-8 からも昼と夜の違いが分か り，夜間は風が弱い傾向にある. 昼は地表面が暖められ て上空よりも温度が上昇するため, 密度的に不安定にな って乱流が発達し風は強くなり, 夜は密度が鉛直的に安 定であるため, 風が弱いと考えられる，そして，昼の風 は上流に向かうため, 上流方向の風の方が夜間に下流に 向かう風よりも強くなる. 一方，天候による違いは，風 向にあらわれるものの, 風速比としては明確ではない.

そこで，昼と夜でそれぞれ近似式を作成した。

$$
\begin{aligned}
& \alpha_{d}=0.0005 L+1.5283 \\
& \alpha_{e}=0.0005 L+1.0681
\end{aligned}
$$

$\alpha_{d}$ は昼間の風速比 $\left(a_{1}, a_{3}\right)$ であり, $L$ との相関係数は $\mathrm{R}=0.691 （ \mathrm{p}<0.006 ）$ となった. $\alpha_{e}$ は夜間の風速比 $\left(a_{2}\right.$, $\left.a_{4}\right)$ であり, $L$ との相関係数は $\mathrm{R}=0.513 （ \mathrm{p}<0.061 ）$ となっ た.

アメダス小河内観測所の風速を用いて式(3), (4)から 各地点の風速を予測し, 実測值と比較したところ（図11），平均二乗誤差（RMSE）は約 $1 \mathrm{~m} / \mathrm{s}$ であった. 9月 2 日の昼間は再現性が悪いが，それ以外の日は風速の傾 向を概衩再現できている，地点ごとにみると，例えば 8 月 31 日や 9 月 3 日は, 風上距離が最も短い St. Cで風速

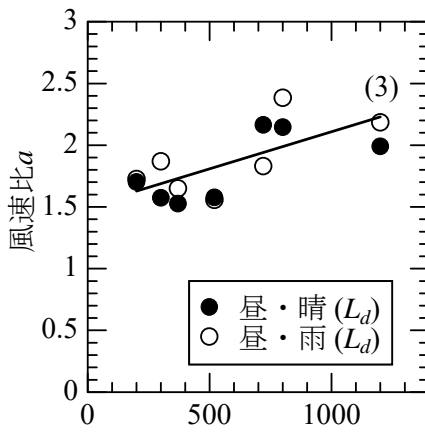

風上距離 $L(\mathrm{~m})$

図-10 風上距離 $L$ と風速比 $\alpha$ の関係

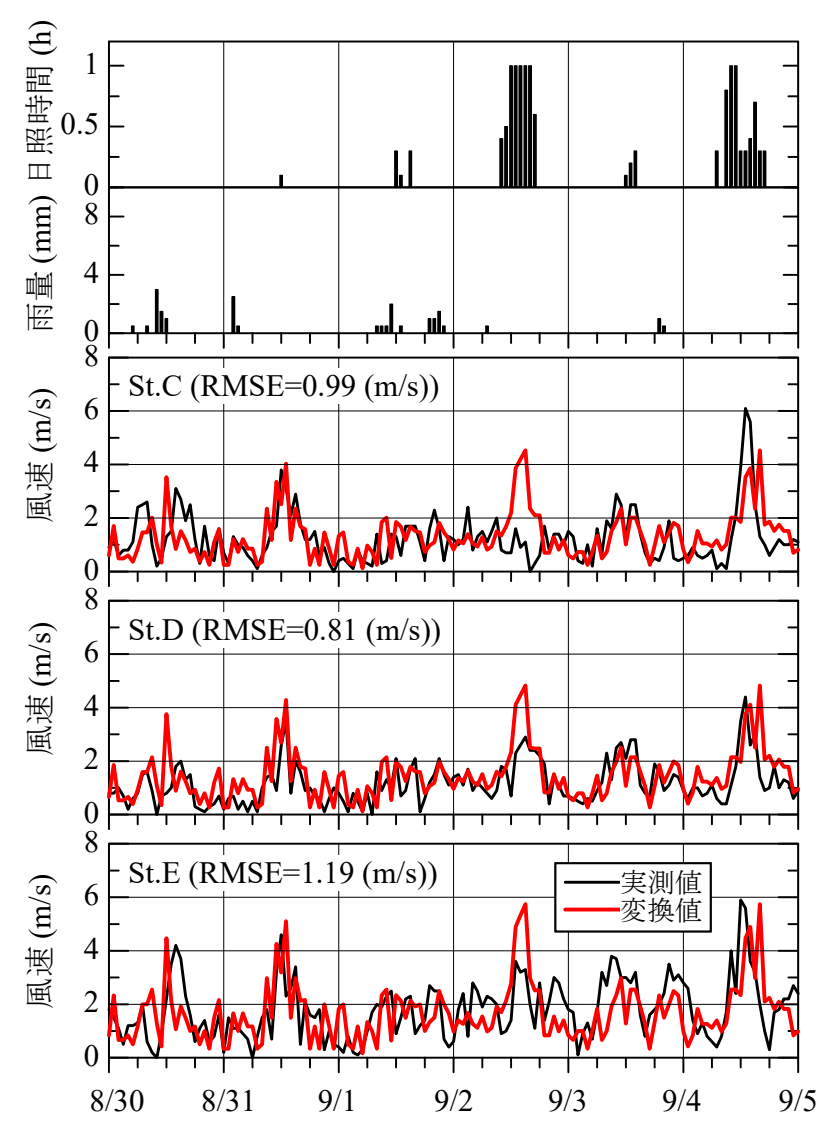

図-11 風速時系列の実測值と予測值の比較

が最も小さく, 風上距離が最も長い St. E で風速が最も 大きくなっており, 風上距離によって風が増大寸る現場 の状況をある程度再現できている.

岡田ら ${ }^{8}$ は, 松原ダム湖の湖心 1 地点において風と波 の観測を行い, 16 方位ごとに風速と吹送距離の関係を 調べたが，その相関性は明確ではなく，波高は Wilson の IV 型の波浪推算式から得た吹送距離則に支配されな いことを示した. しかし，水域の平均的な空間スケール を代表吹送距離とすれば，波高の推算に吹送距離則を適 用できるとしており，谷筫方向に卓越風を考えればよい ことを示している.

本研究の結果は, 既往の研究と合致するものであるが, 新たな知見としては, 蛇行した小河内貯水池の様々な地 点において風と吹送距離の関係が成立すること, 吹送距 
離の取り方は湾曲を考慮せずに，風上側の湖岸から直線 的にとればよいことの 2 点である. 風が谷筋に沿って吹 いているのであれば，ダム堤体（あるいは河川流入部） から当該地点までの総延長を風上距離とすることも考え られるが，蛇行度の大きい小河内貯水池では局所的な直 線領域で風が発達することが分かった.

\section{5. まとめ}

本研究では，山間部にある貯水池の流動シミュレーシ ヨンを高度化するための基礎的な段階として，小河内貯 水池における湖上風の分布特性を把握し，ダム管理所で 観測された 1 地点の風向風速データから湖面の風向風速 分布を推定する手法を検討した.

1) 小河内貯水池の湖面上の8地点に，レジャー用のハン ディー風向風速計を取り付けたブイシステムを設置し, 3ケ月間にわたり風向風速をモニタリングした.

2) 小河内貯水池の湖上風は谷筋に沿って吹く傾向にあり, 晴天日の日中は下流から上流へ向から風，夜間は上流 から下流へ向かう風が吹く周期性があった．ダム管理 所の敷地内で観測されたアメダス風速と湖上風速を比 較すると，湖上の方が風速が大きかった。

3) 観測地点から風上側の湖岸までの直線距離を風上距離 と定義し，アメダス風速に対する湖上風速の比との相 関を調べると，両者には線形的な関係が認められた。 このことは，湖上の局所的な直線領域で風が発達しや すいことを示している.

4) 風上距離から風速比を地点別に推定し, アメダス風速 データから湖上風を予測したところ，風の時空間分布 の傾向を概ね再現できた.

謝辞：本研究を行うにあたり，東京都水道局净水部，水
源管理事務所，小河内貯水池管理事務所の皆様には研究 全般においてご協力頂いた．現地観測では，首都大学東 京水工学研究室の皆様，いであ株式会社国土環境研究所 の皆様にご協力頂いた. ここに記して謝意を表する.

\section{参考文献}

1) Shuichi Endoh, Miwa Watanabe, Hiroki Nagata, Fumihito Maruo, Tetsuya Kawae, Chizuru Iguchi, Yasuaki Okumura: Wind Fields over Lake Biwa and Their Effect on Water Circulation, Jpn.J.Limnol., 56, 4, pp.269-278, 1995.

2) 鶴田康士，石川忠晴 : 小川原湖における風速の現地観測, 水工学論文集, 第43巻, pp.1043-1048, 1999.

3）小林真之，横山勝英，新山雅紀，甲賀大祐，小野崎徹，小 泉明，山崎公子，増子淳，池田麻衣子 : 蛇行した大型貯水 池における湖上風と湖流の空間分布に関する現地観測，水 工学論文集, 第55巻, pp.1537-1542, 2011.

4) 小林真之, 新山雅紀, 横山勝英, 小泉明, 山崎公子，増子 敦, 田村聡志，小林康浩 : 小河内貯水池における地形効果 が流動に及ぼす影響，水道協会雑誌，第81巻第5号，pp.2-9, 2012.

5）竹村明人, 田村直哉, 友清衣利子, 前田潤磁 : 九州内の山 岳地送電線路周辺地域の強風分布推定に向けた検討一周辺 観測值の利用と気象モデルWRFによる推定值の比較一，第 23回風工学シンポジウム, pp.1-6, 2014.

6) 野津剛, 田村哲郎 : 多点観測データに基づく実地形を対象 としたLESの構築, 第22回風工学シンポジウム論文集, pp.389-394, 2012.

7) 後藤智明，柴木秀之 : 陸上地形の影響を考慮した海上風推 算，港湾航空技術研究所報告，32(3)，pp.65-97， 1993.

8) 岡田知也, 小松利光, 荒木和幸, 柴田敏彦, 藤田和夫 : 松原ダム湖の風と波，水工学論文集，第42巻，pp721-726， 1998.

(2016.9.30 受付)

\title{
MONITORING OF THE WIND DISTRIBUTION ON A RESERVOIR AND A SIMPLE ESTIMATION METHOD OF WIND SPEED
}

\author{
Shinya MATSUNAGA, Katsuhide YOKOYAMA, Hiroshige UEDA, Akira KOIZUMI, \\ Kimiko YAMAZAKI, Tomoya KANEYASU and Shinichi KIMURA
}

A monitoring system of wind direction and wind speepd were developed to investigate wind distribution on a meandering reservoir. Small anemometer with compasses for leisure use was attached to the tip of the buoy-system, and it was deployed in eight stations in the Ogouchi Reservoir. The data obtained during three months were compared with the wind data of AMeDAS in the lakefront. It was found that the wind speed measured on the reservoir was approximately two times higher than the wind of AMeDAS, wind blows along a valley, and the ratio of wind speed increased in propotion to the wind fetch. A simple method to estimate a wind speed on the researvoir using AMeDAS data, the ratio of wind speed and the wind fetch was proposed. The estimated wind speed agreed with the meadured wind speed well. 